\title{
Phytopathology
}

\section{Challenges for Managing Candidatus Liberibacter spp. (Huanglongbing Disease Pathogen): Current Control Measures and Future Directions}

\author{
Ryan A. Blaustein, ${ }^{\dagger}$ Graciela L. Lorca, and Max Teplitski
}

First and third authors: Department of Soil and Water Sciences, Genetics Institute, University of Florida, Gainesville; and second author: Department of Microbiology and Cell Science, Genetics Institute, University of Florida, Gainesville.

Accepted for publication 3 October 2017.

\begin{abstract}
Huanglongbing (HLB; "citrus greening" disease) has caused significant damages to the global citrus industry as it has become well established in leading citrus-producing regions and continues to spread worldwide. Insecticidal control has been a critical component of HLB disease management, as there is a direct relationship between vector control and Candidatus Liberibacter spp. (i.e., the HLB pathogen) titer in HLB-infected citrus trees. In recent years, there have been substantial efforts to develop practical strategies for specifically managing $C a$. Liberibacter spp.; however, a literature review on the outcomes of such attempts is still lacking. This work summarizes the greenhouse and field studies that have documented the effects and implications of chemical-based treatments (i.e., applications of broad-spectrum antibiotics, small molecule compounds) and nonchemical measures (i.e., applications of plant-beneficial compounds, applications of inorganic fertilizers, biological control, thermotherapy) for phytopathogen control. The ongoing challenges associated with mitigating $C a$. Liberibacter spp. populations at the field-scale, such as the seasonality of the phytopathogen and associated HLB disease symptoms, limitations for therapeutics to contact the phytopathogen in planta, adverse impacts of broad-spectrum treatments on plant-beneficial microbiota, and potential implications on public and ecosystem health, are also discussed.

Additional keywords: antimicrobials, phytopathogen control, plant microbiota.
\end{abstract}

Huanglongbing (HLB), also known as "citrus greening", has become the most destructive citrus disease worldwide. It is caused by the psyllid-transmitted, phloem-limited bacteria 'Candidatus Liberibacter asiaticus', ' $C a$. Liberibacter americanus', and ' $C a$. Liberibacter africanus' (Bové 2006). These organisms were confirmed as the causative agents of HLB based on reinfection studies even though Koch's postulates cannot be fulfilled due to the inability to culture them ex planta (do Carmo Teixeira et al. 2005; Jagoueix et al. 1996). Infection by any one of these organisms, which were named for their geographic distributions, causes similar symptoms of fruit malformation and altered host phenotype (da Graca and Korsten 2004; do Carmo Teixeira et al. 2005; Jagoueix et al. 1996). Diseased trees develop leaves with characteristic blotchy mottle (i.e., asymmetric leaf yellowing) and produce undersized, lopsided, and greenish-colored fruit that often drops prematurely (Martinelli

${ }^{\dagger}$ Corresponding author: R. A. Blaustein; E-mail: rblauste@ufl.edu

This work was supported by grant 2015-70016-23029 from the United States Department of Agriculture National Institute for Food and Agriculture (USDA NIFA).

(C) 2018 The American Phytopathological Society and Dandekar 2017). HLB-induced host limitations for photoassimilate transport and nutrient uptake, and the associated dieback of canopy and fibrous roots, lead to tree death, typically, within a decade of initial symptom development (Bové 2006). All varieties of cultivated citrus species are susceptible to HLB, though to varying degrees (Folimonova et al. 2009; Gottwald et al. 2012). The economic impacts of the disease have been severe. For example, in the United States, damages to the Florida citrus industry are estimated to have exceeded $\$ 4.5$ billion since ' $\mathrm{Ca}$. Liberibacter asiaticus' was first detected in the state in 2005 (Hodges and Spreen 2012). HLB has already spread to other important citrus growing states as well (e.g., California, Texas) (Kumagai et al. 2013; Kunta et al. 2012), where it is likely to have similar consequences. With $\mathrm{Ca}$. Liberibacter spp. established in over 40 countries (Croxton and Stansly 2014), and considering that citrus is one of the most important fruits in the world in terms of its commercial production market, processing, and global trade (Liu et al. 2012), there is an urgent need for the development of effective strategies to mitigate HLB.

Despite the presence of HLB-like symptoms dating back over a century (in China) and the ongoing efforts to control the disease, there is still a lack of treatment options that are technically feasible, sustainable, and environmentally safe (Grafton-Cardwell et al. 
2013; Martinelli and Dandekar 2017). Controlling the insect vector that transmits $C a$. Liberibacter spp. has been a primary strategy for HLB management, yet it may be limited to only slowing the spread of disease and lessening the severity of consequences in areas that HLB has become well-established (Monzo and Stansly 2017). Although this form of management is essential, especially considering the severity of HLB, it alone cannot mitigate the long-term consequences of the disease. Thus, additional efforts have been made to develop novel strategies to manage HLB. This literature review summarizes the major treatment options for managing $C a$. Liberibacter spp. populations and controlling HLB disease symptoms, including the use of (i) broadspectrum antimicrobials, (ii) ' $C a$. Liberibacter asiaticus'-specific antimicrobials, (iii) thermotherapy, and (iv) compounds that stimulate plant growth and/or boost host defenses. We also discuss the citrus-associated microbiome and implications for citrus health, including what is known about the core citrus microbiome and prospects for implementing microbial biological control to manage $C a$. Liberibacter spp. Strategies for developing genetic resistance to the phytopathogen that are on the horizon are described as well. We conclude with a discussion of ongoing challenges for managing $\mathrm{Ca}$. Liberibacter spp. and mitigating HLB symptoms at the field scale (e.g., resiliency of the phytopathogen, mode of therapeutic delivery, and antimicrobial resistance). Because evaluating treatment effects depends on accurate, reliable pathogen detection methods, we begin our discussion there.

\section{EVALUATING TREATMENT EFFECTS: PHYTOPATHOGEN DETECTION}

The HLB pathogens cannot be cultured for laboratory study, despite recent advancements made based on comparative genomics that may provide insights to how this may be possible in the future (Fagen et al. 2014). Thus, with regard to monitoring HLB and evaluating for potential treatment effects on populations of ' $\mathrm{Ca}$. Liberibacter asiaticus', ' $\mathrm{Ca}$. Liberibacter americanus', and ' $\mathrm{Ca}$. Liberibacter africanus', several nucleic acid-based tests are available for detection and quantification of the (viable) pathogen in plant tissue samples (e.g., leaf and root). Polymerase chain reaction (PCR) is traditionally used to detect the DNA of any one of these phytopathogens in a sample, indicating presence, and quantitative PCR (qPCR) is often used to measure the number of copies of a specific DNA sequence of the phytopathogen, corresponding to its titer (Bové 2006; Zhang et al. 2010). Based on qPCR estimates of gene copy number, the number of cells of $\mathrm{Ca}$. Liberibacter spp. per gram of plant tissue sample can be predicted, as described in the work of Zhang et al. (2011a). From these values, or based on the cycle threshold $(\mathrm{Ct})$ values obtained from $q P C R$, the relative change in phytopathogen population in response to treatment can be quantified. That is, for studies that only reported $\mathrm{Ct}$ values (and not population densities) of $\mathrm{Ca}$. Liberibacter spp. when assessing the impacts of control measures on HLB (Shin et al. 2016; Zhang et al. 2013a), the relative change in phytopathogen titer in response to treatment can still be determined with the $2^{-\Delta \Delta \mathrm{Ct}}$ method (Livak and Schmittgen 2001). Moreover, reverse-transcriptase qPCR (RT-qPCR), which can quantify the abundance of gene transcripts (i.e., reflecting transcriptional activity indicative of the cell's viability), is also used for the detection and/or quantification of the HLB pathogens, as described in works that have focused on the viability of $C a$. Liberibacter spp. in response to chemical treatments (Gardner et al. 2016; Pagliai et al. 2014). In addition, the relative abundance of $\mathrm{Ca}$. Liberibacter spp. within a microbial community (i.e., the proportion of the amount of $\mathrm{Ca}$. Liberibacter spp. to that of all bacteria in the community) can be inferred from the abundances of 16s rRNA genes that are detected in a sample and assigned to different operational taxonomic units (OTUs). Taxon abundances can be estimated based on DNA microarrays (e.g., Phylochip) (Zhang et al. 2013a), clone library sequencing (Sagaram et al. 2009), and high-throughput amplicon sequencing (e.g., Illumina) (Blaustein et al. 2017). Overall, the various studies that have reported on the effects of control measures on $C a$. Liberibacter spp. have used a variety of detection methods, and the interpretation of results is dependent on the respective method used. Throughout this review, we present data from these studies in the context of relative changes in $\mathrm{Ca}$. Liberibacter spp. in response to the treatment, as computed from changes in population densities that have been reported for the phytopathogen, when available, or from raw data for $\mathrm{Ct}$ values using the Livak and Schmittgen (2001) method.

\section{EFFECTS OF CHEMICAL TREATMENTS}

Antimicrobials have played an important role in plant agriculture for controlling a variety of bacterial phytopathogens. The most common examples are chemical therapeutics with active ingredients of streptomycin or oxytetracycline, which have been marketed and used for over 50 years in the United States to mitigate Erwinia amylovora, the pathogen responsible for fire blight of apple, pear, and related ornamental trees (Stockwell and Duffy 2012). In fact, it has been suggested that without incorporating antimicrobial treatments into certain apple and pear production operations to prevent and/or combat fire blight, several popular cultivars and even entire orchards would have been abandoned due to excessive losses (McManus et al. 2002). These compounds, as well as gentamicin and oxalic acid, are also approved for use in several countries in Europe, the Middle East, Central America, and Mexico in order to control bacterial diseases of fruit and vegetable crops caused by members of the genera Erwinia, Pectobacterium, Pseudomonas, Ralstonia, and Xanthomonas (McManus et al. 2002; Stockwell and Duffy 2012). Commercial usage of these treatments varies by location and is subject to extensive regulation based on potential efficacy and associated risk (e.g., fate of the chemicals in the environment, selective pressures associated with evolution and spread of antibiotic-resistant pathogens). In 2016, streptomycin sulfate, oxytetracycline hydrochloride, and oxytetracycline calcium complex were approved for use as foliar sprays to treat HLB in Florida, United States; however, the potential benefits of these compounds are still unclear (Wang et al. 2017a). While judicious use of narrow-spectrum antimicrobials (e.g., small molecules) may be desirable for broadening the toolset of proactive solutions for managing $\mathrm{Ca}$. Liberibacter spp., the use of antibiotics that are closely related to those used in human and veterinary medicine (e.g., streptomycin, oxytetracycline, and other broad-spectrum compounds) should be closely evaluated for the balance of potential benefits and also risks to public health (Chang et al. 2015; Franklin et al. 2016).

Broad-spectrum antimicrobials. When HLB was hypothesized to be of bacterial origin in the 1970s, antibiotic trunk injections, using mainly tetracycline-based compounds, were tested throughout Asia and Africa for their impacts on disease progression and severity (Chiu et al. 1979). However, due to limited success, along with phytotoxic effects and labor costs for annual applications of these compounds in order to limit reinfection (i.e., tetracyclines are bacteriostatic not bactericidal), these treatments were not considered feasible at the time and were discontinued (Zhang et al. 2013a). However, due to the substantial impacts that HLB has had on leading citrus production industries during the past 10 to 15 years, the development of antimicrobial-based strategies to mitigate $\mathrm{Ca}$. Liberibacter spp. is, once again, gaining interest. Several recent greenhouse and field studies have documented the responses of the titer of ' $\mathrm{Ca}$. Liberibacter asiaticus' within leaves of HLB-diseased trees to antibiotic foliar sprays, root drenches, and/or trunk injections (Hu and Wang 2016; Shin et al. 2016; Yang et al. 2016; Zhang et al. 2011a, 2013a). Within these studies, broad-spectrum compounds within antibiotic classes that have varying activities, such as aminoglycosides (streptomycin and kasugamycin), tetracyclines (oxytetracycline), $\beta$-lactams (penicillin), and sulfonamides (sulfadimethoxine and sulfathiazole), were utilized (Table 1). We note that since $C a$. Liberibacter spp. may demonstrate seasonality as it 


\begin{tabular}{|c|c|c|c|c|c|c|}
\hline \multicolumn{7}{|c|}{$\begin{array}{c}\text { TABLE } 1 \\
\text { Antimicrobials that have been tested against huanglongbing (HLB) infection in studies that incorporated quantification } \\
\text { of the phytopathogen }\end{array}$} \\
\hline $\begin{array}{l}\text { Broad antimicrobial } \\
\text { class (target activity) }\end{array}$ & $\begin{array}{l}\text { Antimicrobial } \\
\text { compound(s) }\end{array}$ & $\begin{array}{l}\text { Field/ } \\
\text { greenhouse } \\
\text { (application } \\
\text { method) }\end{array}$ & $\begin{array}{l}\text { Impact on } \\
\text { 'Ca. Liberibacter } \\
\text { asiaticus' } \\
\text { (detection method) }\end{array}$ & $\begin{array}{l}\text { Impact on HLB } \\
\text { symptoms }\end{array}$ & Potential side effects & Reference \\
\hline $\begin{array}{l}\text { Aminoglycosides } \\
\text { (inhibit protein } \\
\text { synthesis) }\end{array}$ & Streptomycin & $\begin{array}{l}\text { Greenhouse } \\
\text { (root drench) }\end{array}$ & $\begin{array}{l}\text { Reduction in population } \\
\text { density in leaves by } \\
\text { more than } 3 \text { log units } \\
\text { within } 3 \text { months after } \\
\text { treatment, yet } \\
\text { regrowth to a level } \\
\text { close to the starting } \\
\text { concentration by the } \\
\text { 6-month time point } \\
\text { (qPCR) }\end{array}$ & Not discussed & No phytotoxicity & $\begin{array}{l}\text { (Zhang et al. } \\
\text { 2011a) }\end{array}$ \\
\hline \multirow[t]{2}{*}{$\begin{array}{l}\beta \text {-Lactams (inhibit } \\
\text { transpeptidation/ } \\
\text { cell wall } \\
\text { modification) }\end{array}$} & Penicillin G & $\begin{array}{l}\text { Field (trunk } \\
\text { injection) }\end{array}$ & $\begin{array}{l}\text { Concentration- } \\
\text { dependent reduction } \\
\text { in titer by } 6 \text { - to } 12 \text {-fold } \\
\text { in leaves of treated } \\
\text { trees compared with } \\
\text { untreated controls at } \\
\text { the 3-month time point } \\
\text { after treatment (qPCR) }\end{array}$ & $\begin{array}{l}\text { Slight increases } \\
\text { in canopy size }\end{array}$ & $\begin{array}{l}\text { No phytotoxicity; little } \\
\text { or no impact on } \\
\text { native bacterial } \\
\text { populations and } \\
\text { penicillin resistance } \\
\text { within populations }\end{array}$ & $\begin{array}{l}\text { (Shin et al. } \\
\text { 2016) }\end{array}$ \\
\hline & & $\begin{array}{l}\text { Greenhouse } \\
\text { (root drench) }\end{array}$ & $\begin{array}{l}\text { Reduction in population } \\
\text { density in leaves by } \\
\text { more than } 3 \text { log units } \\
\text { within } 3 \text { months after } \\
\text { treatment, yet } \\
\text { regrowth to a level } \\
\text { close to the starting } \\
\text { content by the 6- } \\
\text { month time point } \\
\text { (qPCR) }\end{array}$ & Not discussed & No phytotoxicity & $\begin{array}{l}\text { (Zhang et al. } \\
\text { 2011a) }\end{array}$ \\
\hline \multirow[t]{2}{*}{$\begin{array}{l}\text { Sulfonamides } \\
\text { (inhibit metabolic } \\
\text { pathway for folic } \\
\text { acid synthesis) }\end{array}$} & Sulfadimethoxine & $\begin{array}{l}\text { Greenhouse } \\
\text { (root drench) }\end{array}$ & $\begin{array}{l}\text { Approximately a } \\
9 \% \text { lower relative } \\
\text { abundance } \\
\text { (Phylochip), but about } \\
\text { twice as high titer } \\
\text { (qPCR), in leaves of } \\
\text { treated seedlings than } \\
\text { controls at the } 2- \\
\text { month time point after } \\
\text { treatment }\end{array}$ & $\begin{array}{l}\text { Slightly less } \\
\text { chlorosis } \\
\text { development } \\
\text { in canopy of } \\
\text { treated } \\
\text { seedlings than } \\
\text { in that of } \\
\text { controls }\end{array}$ & $\begin{array}{l}\text { Partial deleterious } \\
\text { effects on relative } \\
\text { abundances of } \\
\text { native bacteria }\end{array}$ & $\begin{array}{l}\text { (Yang et al. } \\
\text { 2016) }\end{array}$ \\
\hline & Sulfathiazole & $\begin{array}{l}\text { Greenhouse } \\
\text { (root drench) }\end{array}$ & $\begin{array}{l}\text { Approximately a } \\
7 \% \text { lower relative } \\
\text { abundance } \\
\text { (Phylochip), but about } \\
\text { twice as high titer } \\
\text { (qPCR), in leaves of } \\
\text { treated seedlings than } \\
\text { controls at the } 2- \\
\text { month time point after } \\
\text { treatment }\end{array}$ & $\begin{array}{l}\text { Slightly less } \\
\text { chlorosis } \\
\text { development } \\
\text { in canopy of } \\
\text { treated } \\
\text { seedlings than } \\
\text { in that of } \\
\text { controls }\end{array}$ & $\begin{array}{l}\text { Partial deleterious } \\
\text { effects on relative } \\
\text { abundances of } \\
\text { native bacteria }\end{array}$ & $\begin{array}{l}\text { (Yang et al. } \\
\text { 2016) }\end{array}$ \\
\hline $\begin{array}{l}\text { Tetracyclines } \\
\text { (inhibit protein } \\
\text { synthesis) }\end{array}$ & Oxytetracycline & $\begin{array}{l}\text { Field (trunk } \\
\text { injection) }\end{array}$ & $\begin{array}{l}\text { Depending on the } \\
\text { amount of injection } \\
\text { ports used for } \\
\text { application, the } \\
\text { population density in } \\
\text { leaves decreased } 1 \text { to } \\
3 \text { log units within } 1 \\
\text { month after treatment } \\
\text { (qPCR). It remained } \\
\text { lower in treated trees } \\
\text { than controls for } 9 \\
\text { months, although } \\
\text { population regrowth } \\
\text { occurred during this } \\
\text { time }\end{array}$ & $\begin{array}{l}\text { New flushes did } \\
\text { not display } \\
\text { chlorosis, so } \\
\text { the overall } \\
\text { canopy } \\
\text { appeared } \\
\text { healthier }\end{array}$ & $\begin{array}{l}\text { Moderate } \\
\text { phytotoxicity-brown } \\
\text { discoloration to leaf } \\
\text { burning on some } \\
\text { young flushes }\end{array}$ & $\begin{array}{l}\text { (Hu and Wang } \\
\text { 2016) }\end{array}$ \\
\hline $\begin{array}{l}\text { Small molecules } \\
\text { (inhibit } \\
\text { transcription } \\
\text { factors produced } \\
\text { by that may be } \\
\text { essential for } \\
\text { pathogenesis and } \\
\text { stress tolerance) }\end{array}$ & Tolfenamic acid & $\begin{array}{l}\text { Greenhouse } \\
\text { (foliar spray; } \\
\text { root drench) }\end{array}$ & $\begin{array}{l}\text { Approximately an } 80 \text { to } \\
95 \% \text { reduction in the } \\
\text { expression of } L \text {. } \\
\text { asiaticus genes rplJ } \\
\text { and gyrA in } 75 \% \text { of the } \\
\text { treated seedlings, } \\
\text { indicating substantial } \\
\text { reduction in viable } \\
\text { population (RT-qPCR) }\end{array}$ & $\begin{array}{l}\text { Substantial } \\
\text { improvements } \\
\text { in fibrous root } \\
\text { development } \\
\text { and foliage } \\
\text { appearance }\end{array}$ & No phytotoxicity & $\begin{array}{l}\text { (Gardner et al. } \\
\text { 2016) }\end{array}$ \\
\hline
\end{tabular}




\begin{tabular}{|c|c|c|c|c|c|c|}
\hline \multicolumn{7}{|c|}{$\begin{array}{c}\text { TABLE } 1 \\
\text { (Continued from previous page) }\end{array}$} \\
\hline $\begin{array}{l}\text { Broad antimicrobial } \\
\text { class (target activity) }\end{array}$ & $\begin{array}{l}\text { Antimicrobial } \\
\text { compound(s) }\end{array}$ & $\begin{array}{l}\text { Field/ } \\
\text { greenhouse } \\
\text { (application } \\
\text { method) }\end{array}$ & $\begin{array}{c}\text { Impact on } \\
\text { 'Ca. Liberibacter } \\
\text { asiaticus' } \\
\text { (detection method) }\end{array}$ & $\begin{array}{l}\text { Impact on HLB } \\
\text { symptoms }\end{array}$ & Potential side effects & Reference \\
\hline \multirow[t]{3}{*}{$\begin{array}{l}\text { Combination } \\
\text { treatments } \\
\text { including } \\
\beta \text {-lactams, } \\
\text { aminoglycosides, } \\
\text { and/or } \\
\text { tetracyclines } \\
\text { (see above) }\end{array}$} & $\begin{array}{l}\text { Penicillin G + } \\
\text { streptomycin }\end{array}$ & $\begin{array}{l}\text { Greenhouse } \\
\text { (root drench) } \\
\text { and field } \\
\text { (trunk } \\
\text { injection) }\end{array}$ & $\begin{array}{l}\text { In the greenhouse } \\
\text { study, there was } \\
\text { reduction in population } \\
\text { density by more than } 2 \\
\text { log units within } 2 \\
\text { months following } \\
\text { treatment, which } \\
\text { continued to slightly } \\
\text { decrease during the 6- } \\
\text { month monitoring } \\
\text { period (qPCR). In the } \\
\text { field study, the } \\
\text { population density in } \\
\text { leaves of treated trees } \\
\text { was anywhere from } \\
3.5 \text { to } 5 \text { log units lower } \\
\text { than in those of } \\
\text { controls during } 14 \\
\text { months of monitoring; } \\
\text { however, there were } \\
\text { about } 2 \text { log unit } \\
\text { increases between the } \\
4-\text { and } 14-m o n t h \text { time } \\
\text { points (qPCR). }\end{array}$ & Not discussed & $\begin{array}{l}\text { Slight phytotoxicity in } \\
\text { both studies }\end{array}$ & $\begin{array}{l}\text { (Zhang et al. } \\
\text { 2011a) }\end{array}$ \\
\hline & & $\begin{array}{l}\text { Field (trunk } \\
\text { injection) }\end{array}$ & $\begin{array}{l}\text { The titer in leaves of } \\
\text { treated trees, which } \\
\text { correlated with relative } \\
\text { abundance } \\
\text { (PhyloChip), was } \\
\text { anywhere from 3- to } \\
\text { 30-fold lower than in } \\
\text { those of controls } \\
\text { during } 14 \text { months of } \\
\text { monitoring; however, } \\
\text { seasonal fluctuations } \\
\text { indicated regrowth } \\
\text { (qPCR) }\end{array}$ & $\begin{array}{l}\text { Fluctuating titer } \\
\text { was described } \\
\text { to somewhat } \\
\text { correlate with } \\
\text { symptom } \\
\text { appearance }\end{array}$ & $\begin{array}{l}\text { Partial deleterious } \\
\text { effects on relative } \\
\text { abundances of } \\
\text { native bacteria }\end{array}$ & $\begin{array}{l}\text { (Zhang et al. } \\
\text { 2013a) }\end{array}$ \\
\hline & $\begin{array}{l}\text { Kasugamycin + } \\
\text { oxytetracycline }\end{array}$ & $\begin{array}{l}\text { Field (trunk } \\
\text { injection) }\end{array}$ & $\begin{array}{l}\text { The titer in leaves of treated } \\
\text { trees, which correlated } \\
\text { with relative abundance } \\
\text { (PhyloChip), was } \\
\text { anywhere from 3- to } 30- \\
\text { fold lower than in those } \\
\text { of controls during } 14 \\
\text { months of monitoring; } \\
\text { however, seasonal } \\
\text { fluctuations indicated } \\
\text { regrowth (qPCR) }\end{array}$ & $\begin{array}{l}\text { Fluctuating titer } \\
\text { was described } \\
\text { to somewhat } \\
\text { correlate with } \\
\text { symptom } \\
\text { appearance }\end{array}$ & $\begin{array}{l}\text { Partial deleterious } \\
\text { effects on relative } \\
\text { abundances of } \\
\text { native bacteria }\end{array}$ & $\begin{array}{l}\text { (Zhang et al. } \\
\text { 2013a) }\end{array}$ \\
\hline
\end{tabular}

is capable of moving throughout citrus trees from sources to sinks, upward from roots and downward from canopy at different times of the year (Wang et al. 2017a; Zhang et al. 2013a) relatively longterm trials (i.e., 1+ years) are needed to distinguish antimicrobial effects from noise that may be associated with natural seasonality in phytopathogen populations.

Penicillin G trunk injections (1.0 and $6.0 \mathrm{~g}$ per tree) were recently tested on 2-year-old Ray Ruby grapefruit seedlings in the greenhouse and 7-year-old Ray Ruby grapefruit trees in the field (Shin et al. 2016). Within $24 \mathrm{~h}$, the chemical became distributed throughout the canopy and roots of the seedlings, yet only throughout the canopy, but not roots, of the mature trees (Shin et al. 2016). This suggests possible limitations for thorough chemical transport through the vascular system of citrus trees in the field. According to qPCR analyses from the field study, at 3 months following the trunk injections, the mature leaves from trees receiving the low and high rates of penicillin $\mathrm{G}$ had, on average, a 6-fold and 12-fold decreases in ' $\mathrm{Ca}$. Liberibacter asiaticus' titer, respectively, compared with those of the untreated control trees. Alternatively, the phytopathogen was more than 15-fold lower in the new flushes of trees receiving the higher dose of treatment than within those of control trees $(P<0.05)$ (Shin et al. 2016). Furthermore, the authors reported the chemical applications to have little or no side effects on native bacterial populations or on the proliferation of penicillin-resistant bacteria, as measured by a crude assessment of the bacteria that could grow on generic growth media. Thus, despite the benefits of penicillin G slowing disease progression and promoting no resistance over the 3-month period (Shin et al. 2016), in the absence of long-term studies, the worldwide concern associated with the spread of virulent $\beta$-lactam resistant bacteria (Stockwell and Duffy 2012) may limit the feasibility of commercial applications of this $\beta$-lactam at the field-scale.

The effects of oxytetracycline hydrochloride trunk injections on 5-year-old HLB-infected Hamlin orange trees ( $2 \mathrm{~g}$ per tree) were also recently documented (Hu and Wang 2016). The titers of ' $\mathrm{Ca}$. Liberibacter asiaticus' (as measured by qPCR) within both leaves and roots were reported to have dropped precipitously during the month following treatment, varying between 1 to $3 \log$ unit decreases from the starting density of more than $3 \times 10^{6}$ cells per gram of tissue, depending on the amount of trunk injection ports used ( $\mathrm{Hu}$ and Wang 2016). The population density of ' $\mathrm{Ca}$. Liberibacter asiaticus' remained significantly lower in treated trees than untreated controls over the course of the 9-month study. However, during months 2 to 9 , there was about $1 \log$ of phytopathogen regrowth, perhaps a reflection of the bacteriostatic activity of the antibiotic and/or reinfection of aboveground tissues from ' $\mathrm{Ca}$. Liberibacter asiaticus' present in 
reservoirs such as roots. It is possible that the phytopathogen moves through different plant compartments seasonally, resulting in such observed titer fluctuations. In addition, although improvements in HLB symptoms in response to treatment were described (i.e., no HLB symptoms were present on new growth, so the overall canopy appeared healthier), there were also moderate side effects (i.e., brown discoloration to "leaf burn") on young leaves (Hu and Wang 2016). The concentration-dependent phytotoxicity of oxytetracycline has been reported in several other works (Zhang et al. 2011a, 2012, 2014). Therefore, although oxytetracycline was able to suppress ' $\mathrm{Ca}$. Liberibacter asiaticus' and help alleviate the progression of HLB symptoms, the longevity of these impacts remains unclear because of the phytopathogen regrowth, and an optimal application rate must be used in order to limit phytotoxicity.

Treating HLB with multiple antibiotics at the same time has also been attempted. Using combination therapy was suggested in a greenhouse study that investigated the effects of drenching the roots of HLB-infected Ray Ruby grapefruit seedlings with penicillin $\mathrm{G}\left(1.0 \mathrm{~g} \mathrm{liter}^{-1}\right)$, streptomycin $\left(0.1 \mathrm{~g} \mathrm{liter}^{-1}\right)$, or both of the antibiotics these rates (Zhang et al. 2011a). At 3 months after treatment, the population density of ' $\mathrm{Ca}$. Liberibacter asiaticus' (as estimated based on qPCR) had decreased by about 2 to 4 log units, depending on treatment, from the starting value around $5 \times 10^{5}$ cells per gram of leaf tissue, while that of the untreated controls remained relatively stagnant. However, by 6 months, the reduced level of ' $\mathrm{Ca}$. Liberibacter asiaticus' was only maintained in the leaves of seedlings that had received the combination treatment, while alternatively, the seedlings that were treated with only one compound had leaves with the number of ' $\mathrm{Ca}$. Liberibacter asiaticus' cells that was comparable to that at pretreatment (Zhang et al. 2011a). Thus, synergistic effects of two or more compounds may allow for prolonged antimicrobial activity against the phytopathogen.

A field study on the effects of penicillin and streptomycin via trunk injections on 7-year-old HLB-infected Lee mandarin $\times$ Orlando tangelo trees $(5 \mathrm{~g}$ of penicillin $\mathrm{G}+0.5 \mathrm{~g}$ of streptomycin per tree; $10 \mathrm{~g}$ of penicillin $\mathrm{G}+1 \mathrm{~g}$ of streptomycin per tree) was also described in Zhang et al. (2011a). The lower rate did not demonstrate any phytotoxicity, and compared with untreated control trees, those receiving this rate experienced a 3.5 to $5 \log$ unit reduction in ' $\mathrm{Ca}$. Liberibacter asiaticus' within leaves, as measured by qPCR (Zhang et al. 2011a). However, there were still trends for up to $2 \log$ units of increase in ' $\mathrm{Ca}$. Liberibacter asiaticus' titer in treated trees between 4 and 14 months following treatment, which suggested that continued chemotherapy with these compounds would be necessary in order to manage HLB over the long term. Moreover, Zhang et al. (2013a) built on that field work and attempted trunk injections of penicillin $\mathrm{G}$ and streptomycin ( $5 \mathrm{~g}$ of penicillin $\mathrm{G}+0.5 \mathrm{~g}$ of streptomycin per tree), as well as trunk injections of oxytetracycline and kasugamycin $(2 \mathrm{~g}$ of oxytetracycline hydrochloride $+1.0 \mathrm{~g}$ of kasugamycin per tree) on other HLB-diseased trees at the same site. The titer and relative abundance of ' $\mathrm{Ca}$. Liberibacter asiaticus' in leaves were monitored bimonthly for up to 14 months with qPCR and Phylochip analyses, respectively. Although ' $\mathrm{Ca}$. Liberibacter asiaticus' was suppressed by combination therapies, being anywhere from 3- to 30-fold lower in leaves of trees receiving treatment than in untreated controls, the phytopathogen demonstrated seasonality and regrowth over time (Zhang et al. 2013a). For example, even though the titer was lower in leaves of trees receiving kasugamycin and oxytetracycline than it was in untreated controls during the fall months of the study, all trees experienced increases in titer by about 10 -fold between spring and fall months (Zhang et al. 2013a). Such increases may have been driven by ' $\mathrm{Ca}$. Liberibacter asiaticus' regrowth and, at least partially, by the seasonality of the phytopathogen or that of the insect vector (i.e., since this was a field study, psyllid feeding could have reintroduced inoculum). Moreover, both types of combination treatments induced a change in leaf-associated bacterial populations, as the numbers of bacterial OTUs detected in the midribs of leaves from treated trees comprised only $79.7 \%$ of all OTUs that were detected in the midribs of leaves from control trees (Zhang et al. 2013a). Thus, applications of penicillin with streptomycin and applications of oxytetracycline with kasugamycin were able to suppress the HLB pathogen in a seasondependent manner, which coincided with subtle effects on native microbiota.

In addition to $\beta$-lactams (e.g., penicillin $G$ ), tetracyclines (e.g., oxytetracycline), and aminoglycosides (e.g., streptomycin and kasugamycin), there are a few other broad-spectrum antibiotics that have been used to treat HLB. Yang et al. (2016) reported root drenches of sulfonamides (i.e., $1.0 \mathrm{~g}$ of sulfathiazole sodium, or $1.0 \mathrm{~g}$ of sulfadimethoxine sodium) to have moderate effects on the relative abundance, but not the titer, of ' $\mathrm{Ca}$. Liberibacter asiaticus' in leaves of HLB-infected Ray Ruby grapefruit seedlings in a recent greenhouse study. Specifically, the average relative abundance of the phytopathogen was about 7 to $9 \%$ lower, yet the average titer was 1.5 to 2 times higher, in leaves of treated seedlings than in those of controls (Yang et al. 2016). This may be explained by considering an increase in the numbers of all bacteria within the community, along with the detected increases in numbers of ' $\mathrm{Ca}$. Liberibacter asiaticus'. That is, if the cumulative number of bacteria within leaf communities increased, which could have occurred in response to the antibiotics disrupting a key taxon or taxa that may have kept others in check, then the content of the phytopathogen among the broader community could have still slightly decreased even though the numbers of ' $\mathrm{Ca}$. Liberibacter asiaticus' nearly doubled. Accordingly, there was up to a $35 \%$ decline in total bacterial OTUs within leaves following treatments; several bacterial populations other than ' $C a$. Liberibacter asiaticus', possibly those associated with the fitness of the phytopathogen, may have been selected for during treatment (Yang et al. 2016). Furthermore, the authors noted enhanced effects of both sulfonamides against ' $\mathrm{Ca}$. Liberibacter asiaticus' when they were used in combination with thermotherapy (i.e., when the seedlings were placed in a growth chamber at 40 or $45^{\circ} \mathrm{C}$ for 1 week prior to the root drench treatment). The lack of impacts of sulfonamides on the HLB pathogen at room temperature (i.e., thermotherapy less logistically feasible in the field), along with subsequent adverse effects on native microbiota, make them relatively ineffective and not a feasible option for controlling ' $\mathrm{Ca}$. Liberibacter asiaticus'.

Some of the aforementioned treatment studies were performed following screening tests for a variety of broad-spectrum compounds that were hypothesized to demonstrate activity against Ca. Liberibacter spp. (Zhang et al. 2010, 2011a, 2012, 2013b, 2014). These screens were done by soaking either cuttings or budsticks/scions from HLB-infected plants in a solution containing antimicrobials and then rooting and planting the cuttings or grafting the budsticks/scions onto a healthy stock and monitoring the outcomes. For example, using the grafting approach, Zhang et al. (2014) screened 31 compounds from a variety of antibiotic classes (i.e., aminoglycosides, ansamycins, $\beta$-lactams, cephalosporins, glycopeptides, lincosamides, oxazolidinones, polypeptides, quinolones, sulfonamides, and tetracyclines) for effectiveness and phytotoxicity. From the diverse set of compounds tested, ampicillin, carbenicillin, penicillin, cefalexin, rifampicin and sulfadimethoxine were reported to be most effective in eliminating or, at least, suppressing $\mathrm{HLB}$, based on ' $\mathrm{Ca}$. Liberibacter asiaticus' titers measured (by qPCR) in leaves both the treated scion and the inoculated rootstock (Zhang et al. 2014). This method was also implemented to screen for potential impacts of chemical treatments on citrus-associated microbiota. Zhang et al. (2013b) soaked budsticks taken from HLB-diseased lemon trees in ampicillin- or gentamycincontaining solutions and graft-inoculated healthy grapefruit seedlings. The leaf microbiota were then monitored over 6 months with PhyloChip analyses. Although the ampicillin treatment eliminated ' $C a$. Liberibacter asiaticus', it also induced a $15 \%$ reduction in community richness, compared with the diseased control (Zhang et al. 2013b). Alternatively, while the gentamycin treatment did not impact ' $\mathrm{Ca}$. Liberibacter asiaticus', it, interestingly, caused the 
communities to become less stable as a plethora of low abundance OTUs appeared (Zhang et al. 2013b). Disruption of keystone species in response to antimicrobial solution treatment may have caused that spike in diversity. In summary, the screening methods have also provided insight to the efficacy and potential side effects of several antibiotics that could be considered for use in treating HLB.

Overall, despite the promising advancements for using broadspectrum therapeutics to control $\mathrm{Ca}$. Liberibacter spp., challenges and consequences include seasonality of the pathogen and reestablishment over time, minimal inactivation of the pathogen in older flushes, phytotoxicity, and adverse impacts on richness and diversity of native microbiota (Hu and Wang 2016; Shin et al. 2016; Zhang et al. 2011a, 2013a). Optimization of field treatments with compounds that may suppress $C a$. Liberibacter spp. or combinations of such antibiotics warrants further investigation.

Antimicrobials that specifically target $\mathbf{C a}$. Liberibacter spp. Developing novel therapeutics that may target $C a$. Liberibacter spp. is challenging due to difficulties associated with identifying molecular targets, since the phytopathogen cannot be cultured. Efforts have still been made to search for compounds with activity against ' $\mathrm{Ca}$. Liberibacter asiaticus' based on the information from the pathogen's sequenced genome (Duan et al. 2009) and, also, by using close phylogenetic relatives as model organisms (i.e., Agrobacterium tumefaciens, Liberibacter crescens, and Sinorhizobium meliloti) in culture-based experiments (Akula et al. 2012; Gardner et al. 2016; Pagliai et al. 2014).

Several small molecule compounds that may target molecular pathways essential to the survival of ' $\mathrm{Ca}$. Liberibacter asiaticus' have been identified (Akula et al. 2012; Gardner et al. 2016; Pagliai et al. 2014). For example, SecA is an essential component of the type II bacterial secretion system that moves proteins from the cytosol across or into the cellular membrane (Manting and Driessen 2000). SecA interacts with the SecB chaperone to target SecYEG, functioning as a peripheral ATPase when bound to the complex to facilitate ATP hydrolysis-dependent protein translocation (Economou and Wickner 1994; van den Berg et al. 2004). Akula et al. (2012) identified twenty small molecule compounds that could inhibit SecA activity of the HLB pathogen via molecular docking in silico and then confirmed the antimicrobial activity of five of these compounds in vitro using A. tumefaciens as a culturable model. In addition, Pagliai et al. (2014) characterized a regulon of ' $\mathrm{Ca}$. Liberibacter asiaticus' involved in cell wall remodeling, which contains a transcription factor $(l d t R)$ upstream from a transpeptidase $(l d t P)$ that is essential to its survival. LdtP is needed for cell-wall remodeling under osmotic stresses, which are constantly imposed upon $\mathrm{Ca}$. Liberibacter spp. since it lives within the phloem tissue of infected trees (Pagliai et al. 2014), and LdtR has since been determined to be a global transcriptional regulator of several hundred ' $C a$. Liberibacter asiaticus' genes (Pagliai et al. 2017). Small molecules that bind and inactivate LdtR were identified with thermal shift assays and their activity was validated with DNA binding assays (Pagliai et al. 2014). Several of these compounds (i.e., benzbromarone, hexestrol, and phloretin) demonstrated the ability to down-regulate the expression of $l d t R$ and $l d t P$ in culturable surrogates of ' $\mathrm{Ca}$. Liberibacter asiaticus' (i.e., L. crescens and S. meliloti) and adversely impact the surrogate strains in vitro under artificial osmotic stress conditions (i.e., on growth medium containing relatively high concentrations of $\mathrm{NaCl}$ or sucrose) (Pagliai et al. 2014). The authors further determined that the compounds inhibit the viability of ' $\mathrm{Ca}$. Liberibacter asiaticus' (measured with RT-qPCR) in planta in leaf-soaking assays, suggesting their applicability for future HLB treatment studies (Pagliai et al. 2014). Moreover, another ' $C a$. Liberibacter asiaticus' transcription factor (PrbP) with implications for survival of the phytopathogen was recently characterized (Gardner et al. 2016). PrbP shares homology with CarD (Gardner et al. 2016), an essential RNA polymerase accessory protein in members of the genus Mycobacterium that is involved in pathogenesis, persistence, cell viability, and environmental stress resistance (Srivastava et al. 2013; Stallings et al. 2009). Since PrbP was putatively essential for ' $\mathrm{Ca}$. Liberibacter asiaticus' survival, compounds that may target the protein were investigated and identified in vitro using L. crescens and a model $\gamma$-proteobacterium Escherichia coli (Gardner et al. 2016). One of these compounds (i.e., tolfenamic acid) was also shown to inhibit the viability of ' $C a$. Liberibacter asiaticus' (measured with RT-qPCR) in planta in leaf-soaking assays (Gardner et al. 2016). Tolfenamic acid was further tested for activity against ' $C a$. Liberibacter asiaticus' in HLB-infected Valencia orange seedlings in a long-term greenhouse experiment $(100 \mu \mathrm{M}$ tolfenamic acid applied by foliar spray and root soaking) (Table 1). Based on RT-qPCR analyses, at 11 months following treatment, there had been approximately an 80 to $95 \%$ reduction in the expression of ' $C a$. Liberibacter asiaticus' genes $r p l J$ and gyrA in $75 \%$ of the treated seedlings, suggesting that the compound can lead to substantial inactivation of the metabolically active phytopathogen (Gardner et al. 2016). Importantly, the authors noted that the plants responded to the treatment with substantial improvements in fibrous root growth/development and enhanced foliage appearance. Thus, the target specificity of tolfenamic acid, as well as that of other small molecules that have been suggested to have activity against $C a$. Liberibacter spp. (Akula et al. 2012; Pagliai et al. 2014), would be an interesting avenue of research for future field studies. Compared with broad-spectrum antibiotics, small molecule compounds may be able to more effectively control HLB and minimize adverse ecological impacts (i.e., phytotoxicity and disruption of native microbiota).

\section{ADDITIONAL MEASURES TO CONTROL CA. LIBERIBACTER SPP.}

Thermotherapy. Managing ' $\mathrm{Ca}$. Liberibacter asiaticus' with approaches other than antimicrobial treatment has also been the focus of several studies (Table 2). For example, thermotherapy appears to be somewhat effective at suppressing phytopathogen titer, at least in greenhouse/growth chamber settings (Fan et al. 2016; Hoffman et al. 2012; Yang et al. 2016; Zhang et al. 2016). Hoffman et al. (2012) demonstrated that exposing HLB-infected Ray Ruby grapefruit seedlings to temperatures of $40^{\circ} \mathrm{C}$ for $24 \mathrm{~h}$ or to $42^{\circ} \mathrm{C}$ for $19 \mathrm{~h}$, followed by $30^{\circ} \mathrm{C}$ for $5 \mathrm{~h}$, in growth chambers for only two consecutive days resulted in the titer of ' $\mathrm{Ca}$. Liberibacter asiaticus' dropping by more than 40-fold to a level below the detection limit of qPCR within 2 months. Importantly, although it was noted that a $45^{\circ} \mathrm{C}$ exposure caused severe plant tissue damage, any heat stresses imposed by the 40 or $42^{\circ} \mathrm{C}$ treatment were overcome by the plants (Hoffman et al. 2012). Alternatively, Zhang et al. (2016) reported thermotherapy of HLB-infected Ray Ruby seedlings via exposure to 40 or $42^{\circ} \mathrm{C}$ for $8 \mathrm{~h}$ a day for 1 week to be ineffective at lessening the titer of ' $\mathrm{Ca}$. Liberibacter asiaticus' in leaves, while exposure to $45^{\circ} \mathrm{C}$ for $8 \mathrm{~h}$ a day for 1 week resulted in greater than fivefold decreases in phytopathogen titer by the 2-month time point. In another study, in which HLB-infected tangerine seedlings were exposed to 45 or $48^{\circ} \mathrm{C} 1$ day a week for $4 \mathrm{~h}$ for three consecutive weeks, the titer of ' $\mathrm{Ca}$. Liberibacter asiaticus' within leaves declined by about 30 and $55 \%$, respectively, while that of the controls increased by over $300 \%$ (Fan et al. 2016). Moreover, Yang et al. (2016) performed thermotherapy on HLB-infected Ray Ruby seedlings in growth chambers that were set for a $12 \mathrm{~h}$ exposure of 40 or $45^{\circ} \mathrm{C}$ per day for 1 week, and the higher temperature treatment resulted in a decrease in titer of ' $\mathrm{Ca}$. Liberibacter asiaticus' within leaves by more than $3 \log$ units to a level that was below the qPCR detection limit. The pathogen titers remained below detection throughout 10 months of monitoring posttreatment (Yang et al. 2016). We note that the efficacy of thermotherapy depends on both the aboveground and belowground components of the plant being properly treated. Although thermotherapy is time-consuming 
and expensive process in the field, there have been efforts to develop commercial equipment that could make it more feasible at the larger scale (Trotochaud and Ehsani 2016).

Nonantimicrobial compounds that stimulate plant growth and/or boost host defenses. Other nonantimicrobial HLB treatments include applications of compounds that may boost plant growth and stimulate plant defenses. Canales et al. (2016) reported bimonthly foliar sprays of a brassinosteroid (i.e., $0.084 \mu \mathrm{M}$ epibrassinolide) over the course of 1 year to Valencia orange trees in the field to induce the expression of several key plant defense genes and lower ' $C a$. Liberibacter asiaticus' titers in leaves by approximately sevenfold at the end of that year. The impacts of the routine applications of the plant steroid on seedlings in the greenhouse were even greater, as ' $\mathrm{Ca}$. Liberibacter asiaticus' titer was reported to have reduced from about $10^{6}$ cells $\mathrm{g}^{-1}$ to $10^{4}$ cells $\mathrm{g}^{-1}$ of leaf tissue in as soon as 3 months (Canales et al. 2016). In addition, spray applications of several plant defense regulators (i.e., ascorbic acid [AA], $\beta$-aminobutyric acid [BABA], 2,1,3-benzothiadiazole [BTH], 2-deoxy-D-glucose [2-DDG], and 2,6-dichloroisonicotinic acid [INA]) were reported to somewhat slow down the proliferation of ' $\mathrm{Ca}$. Liberibacter asiaticus' in leaves of 7-year-old HLB-infected Navel orange trees (Li et al. 2016). While the numbers of ' $\mathrm{Ca}$. Liberibacter asiaticus' cells per gram of leaf tissue from treated trees were always within $1 \log$ unit from that of untreated controls, these values were still sometimes significantly different $(P<0.05)$ at time points of 1 year or beyond. In other words, the phytopathogen titer in all trees increased over time, but the rates of increase were sometimes slightly lower in treated trees than controls. The treatments were also described to suppress HLB symptom severity by up to $30 \%$ and have positive impacts on fruit yield and quality (Li et al. 2016). Moreover, spray applications of several other plant-beneficial compounds, including L-arginine and 6-benzyl-adenine (i.e., a synthetic cytokinin) combined with gibberellins, were tested on

TABLE 2

Control measures other than antimicrobials that have been tested against huanglongbing (HLB) in studies that incorporated quantification of the phytopathogen

\begin{tabular}{|c|c|c|c|c|c|c|}
\hline Treatment & $\begin{array}{l}\text { Treatment } \\
\text { details }\end{array}$ & $\begin{array}{l}\text { Field/greenhouse } \\
\text { (application method) }\end{array}$ & $\begin{array}{l}\text { Impact on } \\
\text { 'Ca. Liberibacter } \\
\text { asiaticus' } \\
\text { (detection method) }\end{array}$ & $\begin{array}{l}\text { Impact on } \\
\text { HLB symptoms }\end{array}$ & Side effects & Reference(s) \\
\hline \multirow[t]{4}{*}{ Thermotherapy } & $40^{\circ} \mathrm{C}$ & Greenhouse & $\begin{array}{l}\text { Anywhere from no } \\
\text { change to }>40 \text {-fold } \\
\text { reduction in titer } \\
\text { (qPCR), depending } \\
\text { on the study. About } \\
\text { a } 9 \% \text { reduction in } \\
\text { relative abundance } \\
\text { (PhyloChip) }\end{array}$ & $\begin{array}{l}\text { Some instances of } \\
\text { chlorosis-like } \\
\text { symptoms } \\
\text { being mitigated } \\
\text { over time, though } \\
\text { some cases of } \\
\text { normal symptom } \\
\text { progression }\end{array}$ & $\begin{array}{l}\text { Some cases of } \\
\text { moderate } \\
\text { leaf tissue } \\
\text { damage }\end{array}$ & $\begin{array}{l}\text { (Hoffman et al. 2012; } \\
\text { Yang et al. 2016; } \\
\text { Zhang et al. 2016) }\end{array}$ \\
\hline & $42^{\circ} \mathrm{C}$ & Greenhouse & $\begin{array}{l}\text { Anywhere from no } \\
\text { reduction to }>40 \text {-fold } \\
\text { reduction in titer } \\
\text { (qPCR), depending } \\
\text { on the study }\end{array}$ & $\begin{array}{l}\text { Some instances of } \\
\text { chlorosis-like } \\
\text { symptoms being } \\
\text { mitigated over time, } \\
\text { though some cases } \\
\text { of normal symptom } \\
\text { progression }\end{array}$ & $\begin{array}{l}\text { Some cases of } \\
\text { moderate } \\
\text { leaf tissue } \\
\text { damage }\end{array}$ & $\begin{array}{l}\text { (Hoffman et al. 2012; } \\
\text { Zhang et al. 2016) }\end{array}$ \\
\hline & $45^{\circ} \mathrm{C}$ & Greenhouse & $\begin{array}{l}\text { Anywhere from fivefold } \\
\text { to } 1,000 \text {-fold reduction } \\
\text { in titer in response to } \\
\text { treatment (qPCR). Over } \\
80 \% \text { reduction in relative } \\
\text { abundance (PhyloChip) }\end{array}$ & $\begin{array}{l}\text { Chlorosis-like } \\
\text { symptoms } \\
\text { generally } \\
\text { mitigated } \\
\text { over time }\end{array}$ & $\begin{array}{l}\text { Some cases of } \\
\text { severe } \\
\text { leaf tissue } \\
\text { damage }\end{array}$ & $\begin{array}{l}\text { (Fan et al. 2016; Yang } \\
\text { et al. 2016; Zhang } \\
\text { et al. 2016) }\end{array}$ \\
\hline & $48^{\circ} \mathrm{C}$ & Greenhouse & $\begin{array}{l}\text { Reductions in titer in leaves } \\
\text { of treated trees by about } \\
55 \% \text {, while that in } \\
\text { untreated controls } \\
\text { increased by } \\
\text { over } 300 \% \text { (qPCR) }\end{array}$ & $\begin{array}{l}\text { Chlorosis-like } \\
\text { symptoms } \\
\text { mitigated } \\
\text { over time }\end{array}$ & Not discussed & (Fan et al. 2016) \\
\hline $\begin{array}{l}\text { Chemical inducers } \\
\text { of plant defenses }\end{array}$ & $\begin{array}{l}\text { AA, BABA, BTH, } \\
\text { INA, 2-DDG (used } \\
\text { individually or } \\
\text { in combination) }\end{array}$ & Field (spray) & $\begin{array}{l}\text { No reduction in titer within } \\
\text { leaves; however, the rate } \\
\text { of increase was slowed } \\
\text { compared with } \\
\text { controls (qPCR) }\end{array}$ & $\begin{array}{l}\text { Trees receiving } \\
\text { treatment had } \\
\text { greater fruit yield } \\
\text { and quality than } \\
\text { controls }\end{array}$ & Not discussed & (Li et al. 2016) \\
\hline $\begin{array}{l}\text { Plant-regulating } \\
\text { compounds }\end{array}$ & $\begin{array}{l}\text { L-arginine; 6-benzyl- } \\
\quad \text { adenine }+ \\
\text { gibberellins }\end{array}$ & $\begin{array}{l}\text { Greenhouse (spray) } \\
\text { and field (spray) }\end{array}$ & $\begin{array}{l}\text { No reduction in titer within } \\
\text { leaves of trees receiving } \\
\text { treatments (RT-qPCR) }\end{array}$ & $\begin{array}{l}\text { No phenotypic effects; } \\
\text { however, genes } \\
\text { involved in plant } \\
\text { metabolism and } \\
\text { immune response } \\
\text { were up-regulated }\end{array}$ & Not discussed & $\begin{array}{l}\text { (Martinelli } \\
\quad \text { et al. 2016) }\end{array}$ \\
\hline Brassinosteroids & Epibrassinolide & $\begin{array}{l}\text { Greenhouse (spray) } \\
\text { and field (spray) }\end{array}$ & $\begin{array}{l}\text { Concentration-dependent } \\
\text { reduction in titer within } \\
\text { leaves by about } 160- \\
\text { and } 7 \text {-fold in greenhouse } \\
\text { and field study, } \\
\text { respectively (qPCR) }\end{array}$ & $\begin{array}{l}\text { No HLB symptoms } \\
\text { on new flushes; } \\
\text { genes involved in } \\
\text { plant defense } \\
\text { response were } \\
\text { up-regulated }\end{array}$ & Not discussed & (Canales et al. 2016) \\
\hline \multirow[t]{3}{*}{$\begin{array}{l}\text { Micronutrient-based } \\
\text { compounds }\end{array}$} & $\begin{array}{l}\text { Zinc sulfate } \\
\text { heptahydrate } \\
\left(\mathrm{ZnSO}_{4} \cdot 7 \mathrm{H}_{2} \mathrm{O}\right)\end{array}$ & $\begin{array}{l}\text { Greenhouse (root } \\
\text { drench) }\end{array}$ & $\begin{array}{l}\text { Increases in titer (qPCR) } \\
\text { and relative abundance } \\
\text { (PhyloChip) in leaves }\end{array}$ & $\begin{array}{l}\text { No effects; } \\
\text { symptoms } \\
\text { progressed }\end{array}$ & Not discussed & (Zhang et al. 2016) \\
\hline & $\begin{array}{l}\text { Zineb (i.e., zinc salt of } \\
\text { a bis-dithiocarbamate; } \\
\text { U.S. EPA-approved } \\
\text { agriculture pesticide) }\end{array}$ & $\begin{array}{l}\text { Greenhouse (root } \\
\text { drench) }\end{array}$ & $\begin{array}{l}\text { Increases in titer (qPCR) } \\
\text { and relative abundance } \\
\text { (PhyloChip) in leaves }\end{array}$ & $\begin{array}{l}\text { No effects; } \\
\text { symptoms } \\
\text { progressed }\end{array}$ & Not discussed & (Zhang et al. 2016) \\
\hline & $\begin{array}{l}\text { phosphite combined } \\
\text { with } \mathrm{Mn} \text {-carbonate, } \\
\mathrm{Mn}-, \mathrm{Cu}-\text {, or } \\
\mathrm{Zn} \text {-metalosate; } \\
\text { soluble copper or } \\
\text { silver combined } \\
\text { with a polymer }\end{array}$ & $\begin{array}{l}\text { Field (spray; trunk } \\
\text { injection) }\end{array}$ & $\begin{array}{l}\text { No reduction in titer } \\
\text { in leaves (qPCR) }\end{array}$ & $\begin{array}{l}\text { No effects; } \\
\text { symptoms } \\
\text { progressed }\end{array}$ & Not discussed & (Gottwald et al. 2012) \\
\hline
\end{tabular}


HLB-infected Valencia trees in greenhouse and field studies (Martinelli et al. 2016). RT-qPCR analyses of plant mRNA indicated that the treatments had positive impacts on the abundances of citrus gene transcripts involved in biotic stress responses, starch metabolism, and systemic acquired resistance. Alternatively, the treatments did not have inhibitory effects on ' $\mathrm{Ca}$. Liberibacter asiaticus' or HLB symptom progression (Martinelli et al. 2016). The authors suggested that while certain plantbeneficial treatments can modulate the expression of key citrus defense genes, they might only be able to have mitigating effects against HLB if they are applied frequently before or immediately at the onset of visible HLB symptoms, which was not the case in their study (i.e., HLB in the trees was already at a more progressed stage) (Martinelli et al. 2016). In summary, it appears that plant-beneficial compounds can somewhat help with slowing HLB progression by having positive effects on citrus defenses and growth; however, these forms of treatment may not have strong deleterious impacts on $\mathrm{Ca}$. Liberibacter spp.

Furthermore, since micronutrient deficiencies, especially zinc deficiency, are often associated with HLB symptoms, it can be speculated that applications of zinc-based compounds may help alleviate disease symptoms. However, a recent greenhouse study demonstrated that treating HLB-infected Ray Ruby grapefruit seedlings with zinc sulfate heptahydrate (i.e., $\mathrm{ZnSO}_{4} \cdot 7 \mathrm{H}_{2} \mathrm{O}$; commercially available fertilizer) or zineb (i.e., zinc salt of a bisdithiocarbamate; U.S. Environmental Protection Agency approved agriculture pesticide) actually induced an increase in ' $\mathrm{Ca}$. Liberibacter asiaticus' titer within leaves within 4 months; this increase was $1.5 \times$ greater than the increase experienced in untreated controls during the same time period (Zhang et al. 2016). Thus, receiving these zincbased compounds had expedited proliferation of the HLB pathogen, which may be, at least partially, attributable to the functional highaffinity zinc uptake system encoded in the $C a$. Liberibacter spp. genome (Vahling-Armstrong et al. 2012; Zhang et al. 2016). In a separate field study that attempted treating HLB-diseased citrus trees with micronutrients, spray applications of phosphite combined with zinc-metalosate, manganese-carbonate, manganese-metalosate, or copper-metalosate, and injections treatments of soluble copper or silver mixed with a polymer were reported to have no significant effects on ' $C a$. Liberibacter asiaticus' titer, fruit yield, or juice quality (Gottwald et al. 2012). Collectively, these studies suggest that micronutrient amendments cannot mitigate $C a$. Liberibacter spp., at least when used alone. Although enhanced nutrient programs may promote citrus tree growth for asymptomatic trees or for those in groves with poor soil fertility at early stages of HLB infection, they lack significant effects on HLB-diseased trees that have developed advanced stages of infection (Wang et al. 2017a). Moreover, we note that zinc-based nanoparticles with potential antimicrobial activity (e. g., Zinkicide and $\mathrm{ZnO}-\mathrm{nCuSi}$ gel) have been gaining attention for use to combat citrus pathogens, including ' $\mathrm{Ca}$. Liberibacter asiaticus', and warrant further investigation (Commerford et al. 2016; Graham et al. 2016; Young et al. 2017).

Overall, with regard to nonantimicrobial approaches to control HLB, thermotherapy appears to be the most effective against $C a$. Liberibacter spp., though this has only been confirmed in smallscale settings. Applications of plant growth or defense regulator compounds appear to be beneficial for supporting overall tree health and might be able to slow disease progression; however, they do not lessen the existing pathogen titer. Micronutrient amendments also appear to be generally inconsequential for treating the HLB pathogen. Utilizing some these holistic approaches for phytopathogen control in combination with antimicrobial treatment would be an interesting avenue for future research.

\section{PLANT MICROBIOTA IMPLICATIONS FOR CITRUS HEALTH}

Plant microbiota play critical roles in plant development by providing support for disease control and stress tolerance, among other mechanisms (Andreote et al. 2014; Schlaeppi and Bulgarelli 2015). A growing number of studies have focused on understanding how plant-associated microbial communities change in richness and diversity during disease development (Bulgari et al. 2011; Li et al. 2014; Rastogi et al. 2012; Schreiner et al. 2010; Xu et al. 2012; Zhang et al. 2011b), including that of HLB (Blaustein et al. 2017; Trivedi et al. 2010, 2012; Sagaram et al. 2009; Zhang et al. 2017). Harnessing the beneficial potential of native microbiota may be one of the few logistically and economically feasible solutions for controlling certain phytopathogens that are otherwise difficult to manage, such as $\mathrm{Ca}$. Liberibacter spp.

Core citrus microbiota. Commonly occurring organisms across similar microbiomes comprise a core microbial community that is hypothesized to play key roles in ecosystem functioning within that type of microbial habitat (Gopal et al. 2013; Shade and Handelsman 2012). In a broad field study that incorporated 16S rRNA gene amplicon sequencing, we demonstrated differential associations between the core members of microbial communities of citrus trees and various factors, including HLB disease symptom severity, location (across Florida), cultivar, season, and time (Blaustein et al. 2017). The relative abundance of $C a$. Liberibacter spp. among leaf microbiota (i.e., full leaf samples containing all epiphytes and endophytes) positively correlated with HLB symptom progression and negatively correlated with microbiota alpha diversity (Blaustein et al. 2017). Interestingly, $\mathrm{Ca}$. Liberibacter spp. was detected in leaves of almost all trees that were asymptomatic in appearance $(n=$ 27/29), albeit at low population densities, in addition to all of the HLB-symptomatic trees $(n=41 / 41)$ at relatively higher population densities (Blaustein et al. 2017). Thus, while certain changes in microbiota structure may have been induced by changes in physiology of the host trees, there may have been specific changes that were a precondition to the proliferation of $C a$. Liberibacter spp. and the associated establishment and progression of disease. Moreover, citrus-health-associated microbiota of leaves (e.g., Methylobacterium, Sphingomonas) and roots (i.e., fibrous root samples containing all epiphytes and endophytes) (e.g., Bradyrhizobiaceae, Burkholderiaceae, Kaistobacter, Pseudomonas, Rhodanobacter, and Sinobacteraceae) were identified based on having differential relative abundances in microbial communities of healthy and diseased trees (Blaustein et al. 2017), several of which were previously described in additional studies (Sagaram et al. 2009; Trivedi et al. 2010, 2012; Zhang et al. 2017). Such microbiota that stably associate with citrus may provide functions involved in (i) competing with $C a$. Liberibacter spp. for nutrient resources, limiting its ability to grow and spread, (ii) antibiosis toward the pathogen or other diseaseassociated bacteria, (iii) assistance with host nutrient acquisition, which could help alleviate disease symptom-related nutrient deficiencies, or (iv) induction of host-plant signaling pathways that stimulated plant defense responses (Blaustein et al. 2017). Alternatively, it is possible that some of the aforementioned associations between microbiota and citrus health may be partially attributable to certain microbial taxa simply thriving on relatively healthier plants and/or to the microbiome responses to the potential suppression of plant defenses by $C a$. Liberibacter spp. (Wang et al. 2017a) and changes in plant hormone levels that can occur during vector feeding (Casteel et al. 2012). Characterization of the directional interactions between native microbiota, $C a$. Liberibacter spp., and citrus hosts are needed for formulating novel strategies to manipulate plant-associated microbial communities to mitigate HLB.

Prospects for organic amendments and biological control. Implementing biological control, either alone or in combination with other disease management strategies, such as the use of organic amendments, tolerant/resistant cultivars, or pathogen-free certified planting material, may be feasible for treating emergent woody plant diseases that have proven challenging to control otherwise (e.g., HLB) (Cazorla and Mercado-Blanco 2016). Perhaps $C a$. Liberibacter spp. may be treatable in ways similar to how fungi, 
phytopathogen-specific viruses, and beneficial bacteria and secondary metabolites have been used to treat Fusarium oxysporum (i.e., causative agent of bayoud disease) in date palm, Heterobasidion annosum (i.e., causative agent of root rot) in conifers, and multiple pathogens of grapevine (Compant et al. 2013; El Hassni et al. 2004, 2007; Mgbeahuruike et al. 2011). Moreover, endophytic microbes that possess biocontrol capabilities offer an especially interesting potential for the development of novel agricultural biotechnologies (Cazorla and Mercado-Blanco 2016). For example, inoculating stems of citrus variegated chlorosis (CVC)-diseased Catharanthus roseus with Curtobacterium flaccumfaciens, which was a biocontrol agent originally isolated from asymptomatic citrus, reduced CVC symptoms over time (Lacava et al. 2007). This effect was suggested to have been mediated by (i) the induction of systemic resistance of the host by Curtobacterium flaccumfaciens and/or (ii) antagonistic interactions between Curtobacterium flaccumfaciens and Xylella fastidiosa (i.e., the xylem-limited CVC pathogen), which were previously demonstrated in vitro (Lacava et al. 2004; Lacava et al. 2007). Similarly, Lacava et al. (2006) suggested that direct and/or indirect interactions between $X$. fastidiosa and the biocontrol bacterium Methylobacterium mesophilicum may also affect CVC progression in citrus. Strategies to manage the phloemlimited HLB pathogen with beneficial microbes are an interesting avenue for future research. It was recently reported that Bradyrhizobium and Burkholderia may have implications for beneficial citrus plant-microbe interactions after they were identified as the most dominant genera to be enriched between the citrus rhizosphere and rhizoplane that were adversely impacted by HLB (Zhang et al. 2017). In fact, inoculating citrus seedlings with Burkholderia strains isolated from healthy citrus root microbiota was shown to trigger the expression of citrus genes involved in systemic acquired resistance and limit, though not prevent, ' $\mathrm{Ca}$. Liberibacter asiaticus' infection (Zhang et al. 2017). Also, the mutually exclusive relationships between $\mathrm{Ca}$. Liberibacter spp. and members of the Burkholderiaceae, Micromonosporaceae, and Xanthomonadaceae that have been identified, based on a network analysis of time series data for citrus leafassociated microbial community transitions, present an interesting avenue for future research (Blaustein et al. 2017). These interactions were inferred from negative correlations $(P<0.05)$ that were elucidated from a network analysis of 1-year time series data for bacterial relative abundances in citrus leaf microbiota of HLBaffected trees (Blaustein et al. 2017). Additionally, phage-based therapies have demonstrated efficacy in controlling other citrus diseases caused by bacterial phytopathogens (i.e., citrus canker and citrus bacterial spot) (Balogh et al. 2008) and may have interesting applications for biological control of $\mathrm{Ca}$. Liberibacter spp. if the delivery method can be optimized.

Aside from applications of plant beneficial microbiota, using organic amendments to promote the growth and diversity of resident microbiota are another form of biological control. It was reported that the diversity of microbiota in soils of citrus groves increased when using a fertilizer regime that incorporated a mix of composted manure with lower rates of the inorganic fertilizers that were traditionally used at the site, compared with using only the full rate of inorganic fertilizers (Joa et al. 2014). The microbial diversity of soils may be important for combatting HLB due to implications that native microbiota may have for citrus health.

\section{STRATEGIES FOR DEVELOPING HLB-RESISTANT CITRUS}

Since all varieties of cultivated citrus are susceptible to infection by $C a$. Liberibacter spp. (Hao et al. 2016), breeding HLB-resistant citrus has fundamental challenges. Alternatively, creating transgenic citrus that overexpresses the Arabidopsis thaliana NPRI gene, which is involved in regulating systemic acquired resistance, or that which overexpresses genes involved in production of thionins with antimicrobial activity has been reported to enhance HLB resistance (Dutt et al. 2015; Hao et al. 2016). On the horizon, there are prospects for utilizing an engineered version of Citrus tristeza virus (CTV) in planta to attack $C a$. Liberibacter spp. or to produce a spinach defense gene that may be effective against HLB (Ledford 2017). Researchers are also attempting to use the CRISPRCas9 gene editing tool to create citrus cultivars that are less susceptible to $\mathrm{Ca}$. Liberibacter spp. and/or express genes that may prevent vector transmission (Ledford 2017; Wang et al. 2017a; Zheng et al. 2016). Similar genome editing methods were previously used to confer citrus resistance to another important phytopathogen, Xanthomonas citri, the causative agent of citrus canker (Jia et al. 2016). However, these novel CTV-based gene editing approaches are still several years away from producing desired results and, ultimately, meeting regulatory requirements that would make them feasible and marketable for commercial production operations (Ledford 2017). Thus, controlling the HLB pathogen is still largely limited to the methods described in previous sections of this review.

\section{ONGOING CHALLENGES ASSOCIATED WITH FIELD-SCALE TREATMENT}

Despite ongoing efforts made by growers to modify components of citrus production operations (e.g., fertilizer regime, irrigation schedule, usage of pesticides to manage $C a$. Liberibacter spp. and D. citri) to control HLB, the phytopathogen has spread to infect the vast majority of citrus groves. While chemical compounds with activity against $\mathrm{Ca}$. Liberibacter spp. are becoming recognized (Gardner et al. 2016; Hu and Wang 2016; Pagliai et al. 2014; Zhang et al. 2013a), there are a number of factors that continue to make treatment at the field-scale relatively challenging.

Upon transmission to citrus trees, $C a$. Liberibacter spp. proliferates within and translocates throughout phloem tissue, reaching high, unevenly distributed numbers in leaves and roots (e.g., more than $10^{6}$ cells per gram of leaf tissue) (Hu and Wang 2016; Tian et al. 2014). Thus, in order for antimicrobials to be effective against HLB, they must come in contact with $C a$. Liberibacter spp. by entering the phloem and becoming widely dispersed throughout the vascular system. Although foliar sprays may be the most logical way to deliver treatment at the field-scale, this mode of delivery may not allow for chemical absorbance into phloem due to physical barriers of waxy leaf surfaces and the robustness of plant cell walls. Alternatively, although applying treatment via trunk injection may provide direct transfer of antimicrobials into the plant vascular system, this form of delivery is highly labor intensive in the field. Even with trunk injections, there are still limitations with chemical transport throughout trees to reach the roots (Shin et al. 2016). For example, antimicrobials that are applied above rootstock grafts (e.g., via foliar spray or trunk injection) cannot eliminate $\mathrm{Ca}$. Liberibacter spp. within citrus roots unless they are transported downward to the root system at effective inhibitory concentrations. In addition, while relatively low doses of antimicrobials may be ineffective at suppressing pathogens, higher doses of at least some of the tested antimicrobials are known to have phytotoxic effects. Thus, with inherent challenges for chemical dispersal within trees, the added issue of phytotoxicity when using broad-range antibiotics makes phytopathogen control even more difficult.

There is a latency period between infection and early symptom expression (e.g., blotchy mottle on leaves), during which time infected trees appear asymptomatic (Stansly et al. 2014). While HLB treatments are expected to have highest efficacy if administered at the onset of infection (Martinelli et al. 2016), this timing is not easily anticipated. By the time HLB is recognized and treatments are implemented, $C a$. Liberibacter spp. populations may already be well established and capable of, at least partial, withstanding of antimicrobial treatment effects. For example, when chemical treatments suppress $C a$. Liberibacter spp. within diseased trees, populations of residual $\mathrm{Ca}$. Liberibacter spp. that survive the 
treatment have been reported to regrow over time (Hu and Wang 2016; Zhang et al. 2013a). Thus, the usage of antibiotics may need to continue over time in order to control HLB over the long-term, which introduces problems associated with operation costs and potentially adverse environmental effects. Although it remains largely unknown, there may also be issues associated with resilient $\mathrm{Ca}$. Liberibacter spp. populations and native microbiota becoming resistant to antibiotics that are used, which is concerning with regard to the dissemination of antibiotic resistant bacteria and associated genes through the environment.

Treatments with broad-spectrum antibiotics can have adverse effects on native microbiota (Yang et al. 2016; Zhang et al. 2013a, b), which are known to play an important role in supporting tree health. Under the right circumstances, the plant microbiota can bolster plant productivity by providing protection against phytopathogens, improving tolerance of environmental stresses, priming immune response signaling pathways, and assisting with acquisition of nutrients from soil, among other mechanisms (Andreote et al. 2014; Schlaeppi and Bulgarelli 2015). Finding a treatment with minimal effects on native microbiota, or even developing strategies for biological control (Wang et al. 2017b), may be needed for improving field-scale HLB management.

Although antimicrobials can suppress $\mathrm{Ca}$. Liberibacter spp. within infected trees, high levels of pathogen inoculum are still widespread in areas where HLB has become endemic. For example, in Florida, over 130,000 acres of land previously used for commercial citrus production have become unmanaged or abandoned due to logistical issues associated with maintaining groves infected with HLB (PelzStelinski et al. 2016). These areas remain reservoirs for ' $\mathrm{Ca}$. Liberibacter asiaticus' and $D$. citri. Therefore, even if the phytopathogen is able to be managed within a specific field site, there remains the possibility for reintroduction via vector migration. Thus, efforts to control populations of $D$. citri (i.e., the psyllid vector of ' $C a$. Liberibacter asiaticus' and ' $\mathrm{Ca}$. Liberibacter americanus') and Trioza erytreae (i.e., the psyllid vector of ' $\mathrm{Ca}$. Liberibacter africanus'), which were recently reviewed by Grafton-Cardwell et al. (2013), are critical for field-scale control of $\mathrm{Ca}$. Liberibacter spp.

Overall, although vector control is the primary strategy for HLB management as it may slow the spread of disease and lessen its severity (Monzo and Stansly 2017), there is an urgent need to augment and reduce the dependency on insecticides by identifying feasible measures to mitigate $\mathrm{Ca}$. Liberibacter spp. and associated HLB symptoms (e.g., via applications of antimicrobials, applications of plant-beneficial compounds, biological control). Integration of these approaches with insecticidal controls may be essential for improving the efficacy and sustainability of HLB disease management.

\section{LITERATURE CITED}

Akula, N., Trivedi, P., Han, F. Q., and Wang, N. 2012. Identification of small molecule inhibitors against SecA of Candidatus Liberibacter asiaticus by structure based design. Eur. J. Med. Chem. 54:919-924.

Andreote, F. D., Gumiere, T., and Durrer, A. 2014. Exploring interactions of plant microbiomes. Sci. Agric. 71:528-539.

Balogh, B., Canteros, B. I., Stall, R. E., and Jones, J. B. 2008. Control of citrus canker and citrus bacterial spot with bacteriophages. Plant Dis. 92: 1048-1052.

Blaustein, R. A., Lorca, G. L., Meyer, J. L., Gonzalez, C. F., and Teplitski, M. 2017. Defining the core citrus leaf- and root-associated microbiota: Factors associated with community structure and implications for managing huanglongbing (citrus greening) disease. Appl. Environ. Microbiol. 83:e002010-17.

Bové, J. M. 2006. Huanglongbing: a destructive, newly-emerging, century-old disease of citrus. J. Plant Pathol. 88:7-37.

Bulgari, D., Casati, P., Crepaldi, P., Daffonchio, D., Quaglino, F., Brusetti, L., and Bianco, P. A. 2011. Restructuring of endophytic bacterial communities in grapevine yellows-diseased and recovered Vitis vinifera L. plants. Appl. Environ. Microbiol. 77:5018-5022.

Canales, E., Coll, Y., Hernandez, I., Portieles, R., Rodriguez Garcia, M., Lopez, J., Aranguren, M., Alonso, E., Delgado, R., Luis, M., Batista, L., Paredes, C., Rodriguez, M., Pujol, M., Ochagavia, M. E., Falcon, V., Terauchi, R., Matsumura, H., Ayra-Pardo, C., Llauger, R., del Carmen Perez,
M., Nunez, M., Borrusch, M. S., Walton, J. D., Silva, Y., Pimentel, E., Borroto, C., and Borras-Hidalgo, O. 2016. 'Candidatus Liberibacter asiaticus', causal agent of citrus huanglongbing, is reduced by treatment with brassinosteroids. PLoS One 11:e0146223.

Casteel, C. L., Hansen, A. K., Walling, L. L., and Paine, T. D. 2012. Manipulation of plant defense responses by the tomato psyllid Bactericerca cockerelli and its associated endosymbiont Candidatus Liberibacter psyllaurous. PLoS One 7:e35191.

Cazorla, F. M., and Mercado-Blanco, J. 2016. Biological control of tree and woody plant diseases: An impossible task? BioControl 61:233-242.

Chang, Q., Wang, W., Regev-Yochay, G., Lipsitch, M., and Hanage, W. P. 2015. Antibiotics in agriculture and the risk to human health: How worried should we be? Evol. Appl. 8:240-247.

Chiu, R. J., Tsai, M. Y., and Huang, C. H. 1979. Distribution and retention of tetracyclines in healthy and likubin-ffected Citrus trees following trunk transfusion. Pages 43-152 in: Proceedings ROC-US Coop Science Seminar on Mycoplasma Diseases of Plants, Volume Ser 1. H. J. Su and R. E. McCoy, eds. National Science Council Symposium, Taipei, Taiwan.

Commerford, S., Gerberich, K., Rajasekaran, P., Young, M., Das, S., Graham, J., Santra, S., and Johnson, E. 2016. Citrus canker as a bioassay for systemic bactericidal activity of Zinc nanoparticles. Abstr. Phytopathology 106(suppl.): S4.62.

Compant, S., Brader, G., Muzammil, S., Sessitsch, A., Lebrihi, A., and Mathieu, F. 2013. Use of beneficial bacteria and their secondary metabolites to control grapevine pathogen diseases. BioControl 58:435-455.

Croxton, S. D., and Stansly, P. A. 2014. Metalized polyethylene mulch to repel Asian citrus psyllid, slow spread of huanglongbing and improve growth of new citrus plantings. Pest Manag. Sci. 70:318-323.

da Graca, J. V., and Korsten, L. 2004. Citrus huanglongbing: Review, present status, and futrure strategies. Pages 229-245 in: Diseases of Fruits and Vegetables, Vol. I. Springer, the Netherlands.

do Carmo Teixeira, D., Saillard, C., Eveillard, S., Danet, J. L., da Costa, P. I., Ayres, A. J., and Bové, J. 2005. 'Candidatus Liberibacter americanus, associated with citrus huanglongbing (greening disease) in São Paulo State, Brazil. Int. J. Syst. Evol. Microbiol. 55:1857-1862.

Duan, Y., Zhou, L., Hall, D. G., Li, W., Doddapaneni, H., Lin, H., Liu, L., Vahling, C. M., Gabriel, D. W., Williams, K. P., Dickerman, A., Sun, Y., and Gottwald, T. 2009. Complete genome sequence of citrus huanglongbing bacterium, 'Candidatus Liberibacter asiaticus' obtained through metagenomics. Mol. Plant-Microbe Interact. 22:1011-1020.

Dutt, M., Barthe, G., Irey, M., and Grosser, J. 2015. Transgenic citrus expressing an Arabidopsis NPR1 gene exhibit enhanced resistance against huanglongbing (HLB; citrus greening). PLoS One 10:e0137134.

Economou, A., and Wickner, W. 1994. SecA promotes preprotein translocation by undergoing ATP-driven cycles of membrane insertion and deinsertion. Cell 78:835-843.

El Hassni, M., J'Aiti, F., Dihazi, A., Ait Barka, E., Daayf, F., and El Hadrami, I. 2004. Enhancement of defence responses against bayoud disease by treatment of date palm seedlings with an hypoaggressive Fusarium oxysporum isolate. J. Phytopathol. 152:182-189.

El Hassni, M., El Hadrami, A., Daayf, F., Chérif, M., Ait Barka, E., and El Hadrami, I. 2007. Biological control of bayoud disease in date palm: Selection of microorganisms inhibiting the causal agent and inducing defense reactions. Environ. Exp. Bot. 59:224-234.

Fagen, J. R., Leonard, M. T., McCullough, C. M., Edirisinghe, J. N., Henry, C. S., Davis, M. J., and Triplett, E. W. 2014. Comparative genomics of cultured and uncultured strains suggests genes essential for free-living growth of Liberibacter. PLoS One 9:e84469.

Fan, G. C., Xia, Y. L., Lin, X. J., Hu, H. Q., Wang, X. D., Ruan, C. Q., Lu, L. M., and Liu, B. 2016. Evaluation of thermotherapy against huanglongbing (citrus greening) in the greenhouse. J. Integr. Agric. 15:111-119.

Folimonova, S. Y., Robertson, C. J., Garnsey, S. M., Gowda, S., and Dawson, W. O. 2009. Examination of the responses of different genotypes of citrus to huanglongbing (citrus greening) under different conditions. Phytopathology 99:1346-1354.

Franklin, A. M., Aga, D. S., Cytryn, E., Durso, L. M., McLain, J. E., Pruden, A., Roberts, M. C., Rothrock, M. J., Jr., Snow, D. W., Watson, J. E., and Dungan, R. S. 2016. Antibiotics in agroecosystems: Introduction to the special section. J. Environ. Qual. 45:377-393.

Gardner, C. L., Pagliai, F. A., Pan, L., Bojilova, L., Torino, M. I., Lorca, G. L., and Gonzalez, C. F. 2016. Drug repurposing: Tolfenamic acid inactivates PrbP, a transcriptional accessory protein in Liberibacter asiaticus. Front. Microbiol. 7:1630.

Gopal, M., Gupta, A., and Thomas, G. V. 2013. Bespoke microbiome therapy to manage plant diseases. Front. Microbiol. 4:355.

Gottwald, T. R., Graham, J. H., Irey, M. S., McCollum, T. G., and Wood, B. W. 2012. Inconsequential effect of nutritional treatments on huanglongbing control, fruit quality, bacterial titer and disease progress. Crop Prot. 36:73-82. 
Grafton-Cardwell, E. E., Stelinski, L. L., and Stansly, P. A. 2013. Biology and management of Asian citrus psyllid, vector of the huanglongbing pathogens. Annu. Rev. Entomol. 58:413-432.

Graham, J. H., Johnson, E. G., Myers, M. E., Young, M., Rajasekaran, P., Das, S., and Santra, S. 2016. Potential of nano-formulated zinc oxide for control of citrus canker on grapefruit trees. Plant Dis. 100:2442-2447.

Hao, G., Stover, E., and Gupta, G. 2016. Overexpression of a modified plant thionin enhances disease resistance to citrus canker and huanglongbing (HLB). Front. Plant Sci. 7:1078.

Hodges, A. W., and Spreen T. H. 2012. Economic impacts of citrus greening (HLB) in Florida. IFAS Extension No. FE903.

Hoffman, M. T., Doud, M. S., Williams, L., Zhang, M., Ding, F., Stover, E., Hall, D. G., Zhang, S., Jones, L., Gooch, M., Fleites, L., Dixon, W., Gabriel, D., and Duan, Y. P. 2012. Heat treatment eliminates 'Candidatus Liberibacter asiaticus' from infected citrus trees under controlled conditions. Phytopathology 103:15-22.

$\mathrm{Hu}$, J., and Wang, N. 2016. Evaluation of the spatiotemporal dynamics of oxytetracycline and its control effect against citrus huanglongbing via trunk injection. Phytopathology 106:1495-1503.

Jagoueix, S., Bové, J. M., and Garnier, M. 1996. PCR Detection of the two 'Candidatus' Liberobacter species associated with greening disease of citrus. Mol. Cell. Probes 10:43-50.

Jia, H., Zhang, Y., Orbovic, V., Xu, J., White, F. F., Jones, J. B., and Wang, N. 2016. Genome editing of the disease susceptibility gene CsLOB1 in citrus confers resistance to citrus canker. Plant Biotechnol. J. 15:817-823.

Joa, J. H., Weon, H. Y., Hyun, H. N., Jeun, Y. C., and Koh, S. W. 2014. Effect of long-term different fertilization on bacterial community structures and diversity in citrus orchard soil of volcanic ash. J. Microbiol. 52:995-1001.

Kumagai, L. B., LeVesque, C. S., Blomquist, C. L., Madishetty, K., Guo, Y., Woods, P. W., Rooney-Latham, S., Rascoe, J., Gallindo, T., Schnabel, D., and Polek, M. 2013. First report of 'Candidatus Liberibacter asiaticus' associated with citrus huanglongbing in California. Plant Dis. 97:283.

Kunta, M., Sétamou, M., Skaria, M., Rascoe, J. E., Li, W., Nakhla, M. K., and da Graça, J. V. 2012. First report of citrus huanglongbing in Texas. (Abstr.) Phytopathology 102(suppl.):66.

Lacava, P. T., Araújo, W. L., Marcon, J., Maccheroni, W., Jr., and Azevedo, J. L. 2004. Interaction between endophytic bacteria from citrus plants and the phytopathogenic bacterium Xylella fastidiosa, causal agent of citrus variegated chlorosis. Lett. Appl. Microbiol. 39:55-59.

Lacava, P. T., Li, W., Araújo, W. L., Azevedo, J. L., and Hartung, J. S. 2007. The endophyte Curtobacterium flaccumfaciens reduces symptoms caused by Xylella fastidiosa in Catharanthus roseus. J. Microbiol. 45:388-393.

Lacava, P. T., Li, W. B., Araújo, W. L., Azevedo, J. L., and Hartung, J. S. 2006. Rapid, specific and quantitative assays for the detection of the endophytic bacterium Methylobacterium mesophilicum in plants. J. Microbiol. Methods 65:535-541.

Ledford, H. 2017. Engineered virus in line to battle citrus disease. Nature 545: 277-278.

Li, J., Trivedi, P., and Wang, N. 2016. Field evaluation of plant defense inducers for the control of citrus huanglongbing. Phytopathology 106:37-46.

Li, J. G., Ren, G. D., Jia, Z. J., and Dong, Y. H. 2014. Composition and activity of rhizosphere microbial communities associated with healthy and diseased greenhouse tomatoes. Plant Soil 380:337-347.

Liu, Y., Heying, E., and Tanumihardjo, S. A. 2012. History, global distribution, and nutritional importance of citrus fruits. Compr. Rev. Food Sci. Food Saf. 11:530-545.

Livak, K. J., and Schmittgen, T. D. 2001. Analysis of relative gene expression data using real-time quantitative PCR and the $2^{-\Delta \Delta \mathrm{Ct}}$ method. Methods 25: 402-408

Manting, E. H., and Driessen, A. J. M. 2000. Escherichia coli translocase: The unravelling of a molecular machine. Mol. Microbiol. 37:226-238.

Martinelli, F., and Dandekar, A. M. 2017. Genetic mechanisms of the devious intruder Candidatus Liberibacter in Citrus. Front. Plant Sci. 8:904.

Martinelli, F., Dolan, D., Fileccia, V., Reagan, R. L., Phu, M., Spann, T. M., McCollum, T. G., and Dandekar, A. M. 2016. Molecular responses to small regulating molecules against huanglongbing disease. PLoS One 11:e0159610.

McManus, P. S., Stockwell, V. O., Sundin, G. W., and Jones, A. L. 2002. Antibiotic use in plant agriculture. Annu. Rev. Phytopathol. 40:443-465.

Mgbeahuruike, A. C., Sun, H., Fransson, P., Kasanen, R., Daniel, G., Karlsson, M., and Asiegbu, F. O. 2011. Screening of Phlebiopsis gigantea isolates for traits associated with biocontrol of the conifer pathogen Heterobasidion annosum. Biol. Control 57:118-129.

Monzo, C., and Stansly, P. A. 2017. Economic injury levels for Asian citrus psyllid control in process oranges from mature trees with high incidence of huanglongbing. PLoS One 12:e0175333.

Pagliai, F. A., Coyle, J. F., Kapoor, S., Gonzalez, C. F., and Lorca, G. L. 2017. LdtR is a master regulator of gene expression in Liberibacter asiaticus. Microb. Biotechnol. 10:896-909.
Pagliai, F. A., Gardner, C. L., Bojilova, L., Sarnegrim, A., Tamayo, C., Potts, A. H., Teplitski, M., Folimonova, S. Y., Gonzalez, C. F., and Lorca, G. L. 2014. The transcriptional activator LdtR from 'Candidatus Liberibacter asiaticus' mediates osmotic stress tolerance. PLoS Pathog. 10:e1004101.

Pelz-Stelinski, K. S., Martini, X., Kingdom-Gibbard, H., and Stelinski, L. L. 2016. Patterns of habitat use by the Asian citrus psyllid, Diaphorina citri, as influenced by abiotic and biotic growing conditions. Agric. For. Entomol. 19:171-180.

Rastogi, G., Sbodio, A., Tech, J. J., Suslow, T. V., Coaker, G. L., and Leveau, J. H. J. 2012. Leaf microbiota in an agroecosystem: Spatiotemporal variation in bacterial community composition on field-grown lettuce. ISME J. 6:1812-1822.

Sagaram, U. S., Deangelis, K. M., Trivedi, P., Andersen, G. L., En Lu, S., and Wang, N. 2009. Bacterial diversity analysis of huanglongbing pathogeninfected citrus, using phyloChip arrays and 16S rRNA gene clone library sequencing. Appl. Environ. Microbiol. 75:1566-1574.

Schlaeppi, K., and Bulgarelli, D. 2015. The plant microbiome at work. Mol. Plant-Microbe Interact. 28:212-217.

Schreiner, K., Hagn, A., Kyselkova, M., Moenne-Loccoz, Y., Welzl, G., Munch, J. C., and Schloter, M. 2010. Comparison of barley succession and take-all disease as environmental factors shaping the rhizobacterial community during take-all decline. Appl. Environ. Microbiol. 76:4703-4712.

Shade, A., and Handelsman, J. 2012. Beyond the Venn diagram: The hunt for a core microbiome. Environ. Microbiol. 14:4-12.

Shin, K., Ascunce, M. S., Narouei-Khandan, H. A., Sun, X., Jones, D., Kolawole, O. O., Goss, E. M., and van Bruggen, A. H. C. 2016. Effects and side effects of penicillin injection in huanglongbing affected grapefruit trees. Crop Prot. 90:106-116.

Srivastava, D. B., Leon, K., Osmundson, J., Garner, A. L., Weiss, L. A., Westblade, L. F., Glickman, M. S., Landrick, R., Darst, S. A., Stallings, C. L., and Campbell, E. A. 2013. Structure and function of CarD, an essential mycobacterial transcription factor. Proc. Natl. Acad. Sci. 110:12619-12624.

Stallings, C. L., Stephanou, N. C., Chu, L., Hochschild, A., Nickels, B. E., and Glickman, M. S. 2009. CarD is an essential regulator of rRNA transcription required for Mycobacterium tuberculosis persistence. Cell 138:146-159.

Stansly, P. A., Arevalo, H. A., Qureshi, J. A., Jones, M. M., Hendricks, K., Roberts, P. D., and Roka, F. M. 2014. Vector control and foliar nutrition to maintain economic sustainability of bearing citrus in Florida groves affected by huanglongbing. Pest Manag. Sci. 70:415-426.

Stockwell, V. O., and Duffy, B. 2012. Use of antibiotics in plant agriculture. Rev. Sci. Tech. Off. Int. Epiz. 31:199-210.

Tian, S., Lu, L., Labavitch, J. M., Webb, S. M., Yang, X., Brown, P. H., and He, Z. 2014. Spatial imaging of $\mathrm{Zn}$ and other elements in huanglongbingaffected grapefruit by synchrotron-based micro $\mathrm{x}$-ray fluorescence investigation. J. Experim. Bot. 65:953-964.

Trivedi, P., Duan, Y., and Wang, N. 2010. Huanglongbing, a systemic disease, restructures the bacterial community associated with citrus roots. Appl. Environ. Microbiol. 76:3427-3436.

Trivedi, P., He, Z., Van Nostrand, J. D., Albrigo, G., Zhou, J., and Wang, N. 2012. Huanglongbing alters the structure and functional diversity of microbial communities associated with citrus rhizosphere. ISME J. 6:363-383.

Trotochaud, J., and Ehsani, R. 2016. Commercial-scale thermotherapy for combating citrus greening (huanglongbing). 2016 ASABE Intl. Meeting.

Vahling-Armstrong, C. M., Zhou, H., Benyon, L., Morgan, J. K., and Duan, Y. 2012. Two plant bacteria $S$. meliloti and $C a$. Liberibacter asiaticus, share functional $z n u A B C$ homologues that encode for a high affinity zinc uptake system. PLoS One 7:e37340.

van den Berg, B., Clemons, W. M., Collinson, I., Modis, Y., Hartmann, E., Harrison, S. C., and Rapoport, T. A. 2004. X-ray structure of a proteinconducting channel. Nature 427:36-44.

Wang, N., Pierson, E. A., Setubal, C., Xu, J., Levy, J. G., Zhang, Y., Li, J., Rangel, L. T., and Martins, J., Jr. 2017a. The Candidatus Liberibacter-host interface: Insights into pathogenesis mechanisms and disease control. Annu. Rev. Phytopathol. 55:451-482.

Wang, N., Stelinski, L. L., Pelz-Stelinski, K. S., Graham, J. H., and Zhang, Y. $2017 \mathrm{~b}$. Tale of the huanglongbing disease pyramid in the context of the citrus microbiome. Phytopathology 107:380-387.

Xu, L., Ravnskov, S., Larsen, J., and Nicolaisen, M. 2012. Linking fungal communities in roots, rhizosphere, and soil to the health status of Pisum sativum. FEMS Microbiol. Ecol. 82:736-745.

Yang, C., Powell, C. A., Duan, Y., Shatters, R., Fang, J., and Zhang, M. 2016. Deciphering the bacterial microbiome in huanglongbing-affected citrus treated with thermotherapy and sulfonamide antibiotics. PLoS One 11:e0155472.

Young, M., Ozcan, A., Myers, M. E., Johnson, E. G., Graham, J. H., and Santra, S. 2017. Multimodal generally recognized as safe $\mathrm{ZnO} /$ nanocopper composite: A novel antimicrobial material for the management of citrus phytopathogens. J. Agric. Food Chem. doi.org/10.1021/acs.jafc.7b02526.

Zhang, M., Duan, Y., Zhou, L., Turechek, W. W., Stover, E., and Powell, C. A. 2010. Screening molecules for control of citrus huanglongbing using an 
optimized regeneration system for 'Candidatus Liberibacter asiaticus'infected periwinkle (Catharanthus roseus) cuttings. Phytopathology 100: 239-245.

Zhang, M., Guo, Y., Powell, C. A., Doud, M. S., Yang, C., and Duan, Y. 2014. Effective antibiotics against 'Candidatus Liberibacter asiaticus' in HLBaffected citrus plants identified via the graft-based evaluation. PLoS One 9:e111032.

Zhang, M., Powell, C. A., Guo, Y., Benyon, L., and Duan, Y. 2013a. Characterization of the microbial community structure in Candidatus Liberibacter asiaticus-infected citrus plants treated with antibiotics in the field. BMC Microbiol. 13:112.

Zhang, M., Powell, C. A., Benyon, L. S., Zhou, H., and Duan, Y. 2013b. Deciphering the bacterial microbiome of citrus plants in response to 'Candidatus Liberibacter asiaticus'-infection and antibiotic treatments. PLoS One 8:e76331.

Zhang, M., Powell, C. A., Guo, Y., Doud, M. S., and Duan, Y. 2012. A graftbased chemotherapy method for screening effective molecules and rescuing huanglongbing-affected citrus plants. Phytopathology 102:567-574.
Zhang, M., Powell, C. A., Zhou, L., He, Z., Stover, E., and Duan, Y. 2011a. Chemical compounds effective against the citrus huanglongbing bacterium 'Candidatus Liberibacter asiaticus' in planta. Phytopathology 101: 1097-1103.

Zhang, M. Q., Guo, Y., Powell, C. A., Doud, M. S., Yang, C. Y., Zhou, H., and Duan, Y. P. 2016. Zinc treatment increases the titre of 'Candidatus Liberibacter asiaticus' in huanglongbing-affected citrus plants while affecting the bacterial microbiomes. J. Appl. Microbiol. 120:1616-1628.

Zhang, Y., Du, B.-H., Jin, Z., Li, Z., Song, H., and Ding, Y.-Q. 2011b. Analysis of bacterial communities in rhizosphere soil of healthy and diseased cotton (Gossypium sp.) at different plant growth stages. Plant Soil 339: 447-455.

Zhang, Y., Xu, J., Riera, N., Jin, T., Li, J., and Wang, N. 2017. Huanglongbing impairs the rhizospher-to-rhizoplane enrichment process of the citrus rootassociated microbiome. Microbiome 5:97.

Zheng, Z., Bao, M., Wu, F., Chen, J., and Deng, X. 2016. Predominance of single prophage carrying a CRISPR/cas system in 'Candidatus Liberibacter asiaticus' strains in southern China. PLoS One 11:e0146422. 